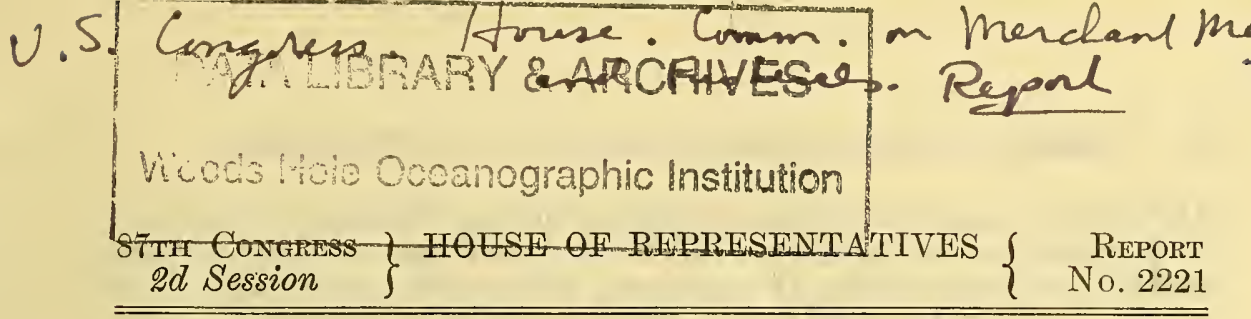

\title{
PROVIDING FOR A COMPREHENSIVE, LONG-RANGE, AND COORDINATED NATIONAL PROGRAM IN OCEANOGRA- $\mathrm{PHY}$
}

August 14, 1962.-Committed to the Committee of the Whole House on the State of the Union and ordered to be printed

Mr. Bonner, from the Committee on Merchant Marine and Fisheries, submitted the following

\section{R E P O R T}

[To accompany H.R. 12601]

The Committee on Merchant Marine and Fisheries, to whom was referred the bill (H.R. 12601) to provide for a comprehensive, longrange, and coordinated national program in oceanography, and for other purposes, having considered the same, report favorably thereon with amendments and recommend that the bill do pass.

The amendments are as follows:

On page 2 , lines 4 and 5 , strike out "by both 'in house' and contract research,".

On page 3 , lines 3 and 4 , strike out "nongovernmental", and insert in lieu thereof "non-Federal".

On page 4, lines 7 and 8 , strike out "Federal Government" and insert in lieu thereof "United States".

On page 4, line 15, after the word "physical,", insert "geological,".

On page 4 , line 16 , insert a comma after the word "meteorological".

\section{PURPOSE}

The purpose of this bill is to provide for the development and maintenance of a coordinated, comprehensive, and long-range national program of oceanography, under the overall direction of the Office of Science and Technology, with clear responsibility to the President and to the Congress.

Such a program is recognized by the President, the executive departments, and the Congress, as being necessary in the national interest in the coming years.

The bill provides a proper and workable solution to the problem of coordinating the activities in the marine sciences of a large number of

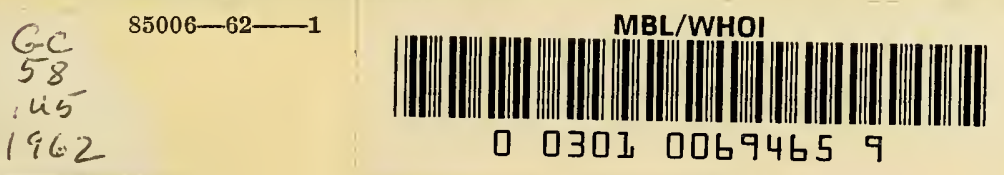




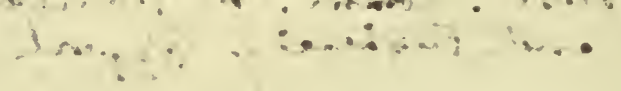

Government agencies without destroying or impeding their autonomy. It permits the maximum use of all the technical resources, knowledge, and skills of the country, Government, private or commercial, in an endearor of equal or greater importance than the exploration of space.

\section{NEED FOR THE LEGISLATION}

Through its Subcommittee on Oceanography your committee has been studying and investigating the status of the marine sciences in the United States and the need for a national program in oceanography. The committee's efforts in this direction are summarized later in this report under the heading, "Background of the Legislation." Your committee feels that the clearest statement of the needs of the United States for a broad national effort in oceanography can be found in President Kennedy's message to Congress on oceanography on March 29, 1961 (Executive Communication No. 734). The following excerpt from that message states the case comprehensively, yet concisely:

The seas around us, as I pointed out in my message to the Congress on February 23, represent one of our most important resources. If vigorously dereloped, this resource can be a source of great benefit to the Nation and to all mankind.

But it will require concerted action, purposefully directed, with vision and ingenuity. It will require the combined efforts of our scientists and institutions, both public and private, and the coordinated efforts of many Federal agencies. It will involve substantial investments in the early years for the construction and operation of ship and shore facilities for research and surveys, the development of new instruments for charting the seas and gathering data, and the training of new scientific manpower.

We are just at the threshold of our knowledge of the oceans. Already their military importance, their potential use for weather predictions, for food, and for minerals are evident. Further research will undoubtedly disclose additional uses.

Knowledge of the oceans is more than a matter of curiosity. Our very survival may hinge upon it. Although understanding of our marine environment and maps of the ocean floor would afford to our military forces a demonstrable advantage, we have thus far neglected oceanography. We do not have adequate charts of more than 1 or 2 percent of the oceans.

The seas also offer a wealth of nutritional resources. They already are a principal source of protein. They can provide many times the current food supply if we but learn how to garner and husband this self-renewing larder. To meet the vast needs of an expanding population, the bounty of the sea must be máde more available. Within two decades, our own Nation will require over a million more tons of seafood than we now harvest.

Mineral resources on land will ultimately reach their limits. But the oceans hold untapped sources of such basic minerals as salt, potassium, and magnesium in virtually limitless quantities. We will be able to extract additional 
elements from sea water, such as manganese, nickel, cobalt, and other elements known to abound on the ocean floor, as soon as the processes are developed to make it economically feasible.

To predict, and perhaps some day to control, changes in weather and climate is of the utomost importance to man everywhere. These changes are controlled to a large and yet unknown extent by what happens in the ocean. Ocean and atmosphere work together in a still mysterious way to determine our climate. Additional research is necessary to identify the factors in this interplay.

These are some of the reasons which compel us to embark upon a national effort in oceanography. $* * *$

WHAT THE BILL DOES: SECTION-BY-SECTION ANALYSIS

Section 1 identifies the legislation as the "Oceanographic Act of 1962."

Section 2 declares it to be the policy of the United States to develop and maintain a coordinated, comprehensive, and long-range national program in oceanography. In furtherance of this policy it is declared that adequate provision must be made for continuing, systematic research, studies, and surveys of the ocean and its resources, and of the total marine environment.

It is further declared to be the policy of the United States to implement such national program through the balanced participation and cooperation of all qualified persons, organizations, institutions, agencies or corporate entities, whether governmental, educational, nonprofit, or industrial.

It is the intent of this section to make it clear that a program of the breadth and magnitude here envisaged can be fully effective only if all the available knowledge, skills, and energies of the Nation are called upon. For example, research projects should be carried out through utilization of all appropriate means, including "in-house" capabilities, grants, and contracts.

Section 3 places the primary responsibility for assuring the implementation of the national program within the newly created Office of Science and Technology in the Executive Office of the President.

The Office of Science and Technology, established by Reorganization Plan No. 2 of 1962, is directed to establish the program. To that end it is further directed to issue a statement of national goals, including methods for achieving those goals, and defining the responsibility of the departments, agencies, and instrumentalities of the United States to carry out the national program on an integrated, coordinated basis.

For long-range flexibility subsection 3 (b) provides that the program may be revised from time to time as determined by the Office.

Subsection 3(c) requires consultation by the Office with all interested departments, agencies, and instrumentalities of the United States, as well as capable non-Federal institutions and industrial concerns where appropriate.

In connection with the provisions of section 3 , the following statement contained in the recent "Report to the President on Government Contracting for Research and Development" (sometimes referred to 
as the "Bell Report"), submitted by the Director of the Bureau of the Budget in cooperation with the Secretary of Defense, Chairman of the Atomic Energy Commission, Administrator of the National Aeronautics and Space Administration, Director of the National Science Foundation, Chairman of the Civil Service Commission, and the Special Assistant to the President for Science and Technology is highly pertinent. Among its conclusions the report states as follows:

The basic purposes to be served by Federal research and development programs are public purposes, considered by the President and the Congress to be of sufficient national importance to warrant the expenditure of public funds. 'The management and control of such programs must be firnly in the hands of full-time Government officials clearly responsible to the President and the Congress.

Tour committee believes that placing the responsibility for establishing a national oceanographic program, defining its scope and coordinating its activities within the new Office of Science and Technology is in full accord with the sound conclusions expressed in the above-mentioned report.

Section 4 provides for the establishment in the Office of Science and Technology of the position of Assistant Director for Oceanography, who shall be appointed by the President, by and with the advice and consent of the Senate, and who shall receive compensation at the rate of $\$ 19,000$ per annum. The Assistant Director shall perform such duties and exercise such powers as the Director of the Office shall prescribe.

Your committee riews this section as most important.

It is recognized that the new Office of Science and Technology, under Reorganization Plan No. 2, is a statutory successor to the former Executive order-created Federal Council for Science and Technology, made up of a number of committees, including the Interagency Committee on Oceanography.

Just as the Federal Council was a broad gaged and flexible agency in its treatment of scientific subjects and related programs, the new Office should likewise be.

Consideration has been given to whether or not it is desirable to provide for an Assistant Director for Occanography, in view of the other many and varied activities coming under the Office. We bclieve the advantages rastly outweigh the disadvantages.

The scope of scientific effort embraced by the former Federal Council for Science and Technology, and now by its successor, the Office of Science and Technology, is such that no simple standards of supervision can be established which would be applicable equally to the various constituent suborganizations. On the other hand, the record, in Congress and in the executive branch, in the past several years has shown that occanography is a subject of prime national importance. In view of the size and complexity of a coordinated national oceanographic program it is essential that the Director have the services of a competent, full-time assistant.

Section 5 authorizes the Director of the Office of Science and Technology to appoint a seven-member Advisory Committee for Oceanography, who shall meet at the call of the Director for the purpose of reviewing the national program and make recommendations with respect thereto. 
An advisory committee is a most important part of any national program. Beyond the Government departments today there is a vast potential for guidance of a truly effective national program. Magnificent talent is a vailable in our fine not-for-profit specialized, scientific institutions, our universities and colleges, our State activities, and in our developing commercial and industrial laboratories, who can and will offer valuable suggestions to lead the way to an overall program which will work in behalf of the national interest. The Advisory Committee should include as broad representation as possible from such sources.

No term of office is prescribed and no qualifications are set forth with regard to the membership of the Advisory Committee. Your committee believes that this is best left to the exercise of discretion in the executive branch by the Director of the Office of Science and Technology.

Section 6 requires the Director of the Office of Science and Technology to make a report on oceanography annually, during the month of January, to the President and the Congress. 'The Director's report would contain the following:

(1) The general status of oceanography.

(2) The status of research, development, studies, and surveys conducted (directly or indirectly) by the United States in furtherance of oceanography, together with application of such research, development, studies, and surveys.

(3) A detailed analysis of the amounts proposed for appropriation by Congress for the ensuing fiscal year for each of the Departments, agencies, and instrumentalities of the Government to carry out the purposes of this act.

(4) Current and future plans and policies of the United States with respect to oceanography.

(5) Requests for such legislation as may be necessary to carry out as rapidly as possible the purposes of this act.

The report of the Director of the Office of Science and Technology is of great importance. This is the means for communication with the Congress. This is the means for assuring concise and clear statements of objectives and accomplishments on a continuing basis. This is the means by which the Congress can be advised of and knowledgeably participate in new programs.

Section 7 defines the term "oceanography" in a broad sense as including-

the acquisition, assembling, processing, and dissemination of all scientific and technological oceanographic and related environmental data, including, but not limited to, physical, geological, biological, fisheries, hydrographic and coastal survey, meteorological, climatological, and geophysical data.

Finally, your committee recognizes the overlapping nature of many of the disciplines that fall within the term "oceanography." However, nothing is so black or so white that it is possible to drew precisely the perimeters of "oceanography." It is not necessary that it should be done. Primarily we are dealing with the vast oceanic environment. Fringe problems can be met and handled as they arise. The program urged by your committee should be defined in the broadest possible terms. 


\section{BACKGROUND OF THE LEGISLATION}

H.R. 12601 is a clean bill, introduced at the direction of your committee's Subcommittee on Oceanography as the product of some three and a half vears of study and a number of hearings, both investigative and legislative in character. H.R. 12601 supersedes H.R. 4276.

Your committee's interest in the problem of development of a coordinated national program in oceanography was stimulated in January 1959, just prior to the release of chapter I, "Introduction and Summary of Recommendations" of a report entitled "Oceanography 1960-70," prepared by the Committee on Oceanography of the National Academy of Sciences-National Research Council. The work of that Committee on Oceanography, hereinafter referred to as NASCO, was made possible by the sponsorship of several Government agencies having extensive interest in the oceans, i.e., the Atomic Energy Commission, Bureau of Commercial Fisheries of the Department of the Interior, National Science Foundation, and the Office of Naval Research, Department of the Nary.

Many other Government agencies engage in activities involving in greater or lesser degree some phase of oceanography. The term "oceanography" embraces many scientific disciplines. Indeed, it encompasses the scientific study of all aspects of the oceans, their boundaries and their contents. Oceanographic research is undertaken in a variety of private and Government laboratories. Important segments of industry are engaged in various types of oceanographic activity, with new prospects for the exploitation of marine environment opening up with increasing frequency.

In view of the NASCO report and the obvious responsibilities among many departments for one or more elements embraced within the term "oceanography," your committee's first step was the appointment of a subcommittee to study the NASCO report and hold thorough hearings to ascertain the extent of the Government's current participation in this field. The subcommittee was charged with responsibility to assess the status of the marine sciences in the United States, both within and without the Government, and make recommendations for legislation or other action that might be needed to derelop and maintain an effective national oceanographic program for the future. During this phase of its inquiry no legislation was before the subcommittee.

General hearings, held during 1959 and 1960, produced more than 400 pages of printed testimony, with witnesses appearing on behalf of such agencies as the U.S. Navy Hydrographic Office, the Coast and Geodetic Survey, the Office of Naval Research, the Atomic Energy Commission, the Fish and Wildlife Service, Navy Bureau of Ships, Federal Maritime Board and Maritime Adninistration, the Weather Bureau, Beach Erosion Board, Coast Guard, Woods Hole Oceanographic Institution, Scripps Institution of Oceanography, and others. In addition, the subcommittee and its staff met on many occasions with the members of the National Academy of Science's Committee on Oceanography in a cooperative effort to find the most effective mechanism for fostering and maintaining a well balanced national program. 
Coordination of the efforts of the existing departments and agencies concerned with various aspects of oceanography appeared to be the only practical and effective approach.

After about 2 years of consideration of all aspects of the problem of developing a governmental mechanism for establishing a national program of oceanography on a continuing basis, it was concluded that a high-level group composed of the top officials of the departments and agencies concerned with the various major disciplines held the most promise for effective coordination. H.R. 4276, a bill to expand and develop the aquatic resources of the United States including the oceans, estuaries, and rivers, the Great Lakes and other inland waters, to enhance the general welfare, and for other purposes, was introduced by the distinguished former chairman of the Subcommittee on Oceanography, the Honorable George P. Miller of California.

H.R. 4276 provided for the establishment of a National Oceanographic Council composed of the chief officials of the departments and agencies of the Government concerned in any important respect with oceanography. In addition, it called for the establishment by the Council of a National Oceanographic Data Center and a National Instrumentation Test and Calibration Center. The bill also contained other provisions dealing with such matters as the title to oceanographic research vessels and certain functions of the Smithsonian Institution.

Both open and executive hearings were held on H.R. 4276, and S. 901 (which, among other things, would have assigned the coordination function to the National Science Foundation). Reports, testimony, and advices from the executive agencies were to the effect that, while the objectives of the House and Senate bills were favored, the same objectives could be accomplished, without legislation, through the Interagency Committee on Oceanography, a subcommittee within the existing structure of the Federal Council of Science and Technology.

Your committee carefully considered the objections expressed by the departments and the Bureau of the Budget of the Executive Office of the President, and prepared a draft revision of the original bill, designed to overcome such objections as far as possible and refine the concept of an oceanographic council in the light of testimony developed during the hearings on H.R. 4276.

The draft revision eliminated such features of the original bill as the establishment of a National Oceanographic Data Center, which had by that time been established administratively, and the establishment of a National Instrumentation Test and Calibration Center which was planned to be set up under existing administrative procedures. Certain other provisions of the original bill dealing with such matters as the title to oceanographic vessels and additional authority for the Smithsonian Institution were also eliminated and embodied in separate legislation.

In line with departmental suggestions, the revision provided for enlarging departmental representation on the Council. As an outgrowth of expert testimony presented to the committee during the hearings on the original bill, the revised draft provided for a small, high-level staff office to be headed by an official designated "The Oceanographer of the United States." In addition, the revised draft would have established a fund in the Treasury to be known as the special aquatic research fund, from which the Council would be au- 
thorized to grant to participating governmental agencies from tine to time amounts determined by the Council to be necessary in the conduct of oceanographic research to aid in carrying out the national program.

The purpose of the revised draft was to provide for the creation of a council with sufficient decisionmaking powers and authority; an executive director to whom the Congress could look for regular periodic reports on the status of the oceanographic program; a small but adequate staff to assist the Council in programing activities; and an appropriation of money which could be directed to any agency of the Government to enhance the total annual program and alleviate the inflexibility of the usual 3-year budget cycle. The proposed revision conformed to the recommendations of the Committee on Oceanography of the National Academy of Sciences-National Research Council, as set forth in their letter to the chairman of the Subcommittee on Oceanography on July 27, 1961.

The departments and the Bureau of the Budget expressed their objections to the revised draft of H.R. 4276 on grounds similar to their objections to the original bill, i.e., the Interagency Committee on Oceanography of the Federal Council for Science and Technology was adequately performing, coordinating, and program-planning functions.

Objections were also directed to the provisions of the revised draft which set up a special aquatic research fund and established an Office of Oceanographer of the United States. The Bureau of the Budget further noted that the revised bill made no mention of the relationship of the proposed Council to the President, stating that it is the President's ultimate responsibility to formulate national programs for the executive branch and that "it is also important that clear" Presidential authority over the management of the executive branch be assured." These objections have been met and overcome in the bill hereby reported.

Notwithstanding the objections noted above, it may be seen that the views of your committee and those of the executive branch have been in full accord as to objectives; have differed as to some details; and have been apart solely on the question of whether the coordinating mechanism for a national oceanographic program should operate exclusively under Executive sanction or should have a legislative base with responsibility to Congress, as well as to the President.

Noting the continued departmental objections, your committee sought resolution of the different viewpoints through the conduct of hearings early this year (February 2S, March 1 and 2, 1962), designated as a "Study of the Effectiveness of the Committee on Oceanography of the Federal Council for Science and Technology."

Your committee found that the ICO, under the very able chaimanship of Dr. James Wakelin, Assistant Secretary of the Navy for Research, was doing a creditable job, with its subcommittees made up of employees from the various affected agencies, though at a much lower level representation of departments on the ICO than the Cabinet-level membership of the proposed Council under the Miller bill (H.R. 4276). However, its agency heads were under no obligation to, and did not, work in concert to the extent contemplated by H.R. 4276. Moreover, there was no clear responsibility to the Congress, either directly through the $\mathrm{ICO}$, or indirectly, on a representative basis, through the Federal Council of Science and Technology. 
The ICO with its ad hoc subcommittees, was one of a dozen miscellaneous, albeit highly important, "boxes" on the organization chart of the Federal Council for Science and Technology. As of February of this year the other groups, or advisory committees, of the Federal Council were: International Committee, Technical Committee on High Energy Physics, Interdepartmental Committee for Atmospheric Sciences, Committee on Natural Resources, Coordinating Committee for Materials R. \& D., Standing Committee, Committee on Long Range Planning, Subcommittee on Water Resources Research, Ad Hoc Panel on Laboratory Astrophysics, Panel on Environment and Incentives for Research, and Ad Hoc Panel on Methods for Improving: Federally Financed Research.

On the basis of these hearings and other studies of the problem, your committee concluded that the existing structure was inadequate to carry forward, on an effective long-range basis, the national program in oceanography which, otherwise, all agreed should be established and maintained.

Your committee has worked closely and cooperatively with all the departments concerned with oceanography and others interested in and responsible for the technical and organizational development of a national program. Thus, when it appeared that some overall statutory base was to be proposed to the Congress, applicable to the whole broad spectrum of scientific research and related interagency problems, your committee deferred legislative action in order to seek an approach in conformity with any new reorganization plan that might be recommended by the President and approved or acceded to by the Congress.

On March 29, 1962, the President transmitted to the Speaker of the House, Reorganization Plan No. 2 of 1962, under the provisions of the Reorganization Act of 1949, as amended. In the absence of disapproval by either the House or the Senate, plan No. 2 became effective on June 8, 1962.

Part I of the reorganization plan creates an Office of Science and Technology in the Executive Office of the President; creates a Director and Deputy Director, transfers coordinating functions from the National Science Foundation to the new Office; and makes provision for personnel under the classified civil service.

Part II of the plan provides for certain reorganizations within the National Science Foundation designed to strengthen the capability of the Director of the Foundation to exert leadership and otherwise further the effectiveness of administration of the Foundation.

We are here concerned only with part I of the plan.

It is pertinent to quote from the President's message transmitting the reorganization plan to the Congress (H. Doc. No. 372, 87th Cong., 2d sess., Mar. 29, 1962):

The new arrangements incorporated in part $I$ of the reorganization plan will constitute an important development in executive branch organization for science and technology. Under those arrangements the President will have permanent staff resources capable of advising and assisting him on matters of national policy affected by or pertaining to science and technology. Considering the rapid growth and far-reaching scope of Federal activities in 
science and technology, it is imperative that the President have adequate staff support in developing policies and evaluating programs in order to assure that science and technology are used most effectively in the interests of national security and general welfare.

To this end it is contemplated that the Director will assist the President in discharging the responsibility of the President for the proper coordination of Federal science and technology functions. More particulariy, it is expected that he will advise and assist the President as the President may request with respect to-

(1) Major policies, plans, and programs of science and technology of the various agencies of the Federal Government, giving appropriate emphasis to the relationship of science and technology to national security and foreign policy, and measure for furthering science and technology in the Nation.

(2) Assessment of selected scientific and technical developments and programs in relation to their impact on national policies.

(3) Review, integration, and coordination of major Federal activities in science and technology, giving due consideration to the effects of such activities on non-Federal resources and institutions.

(4) Assuring that good and close relations exist with the Nation's scientific and engineering communities so as to further in every appropriate way their participation in strengthening science and technology in the United States and the free world.

(5) Such other matters consonant with law as may be assigned by the President to the Office.

In testimony before a subcommittee of the House Committce on Government Operations on April 17, 1962, Hon. Elmer B. Staats, Deputy Director of the Bureau of the Budget, in describing the intent of Reorganization Plan No. 2 of 1962, stated:

The other thing that this does, as I pointed out in my statement, is that it would make it possible to have someone who is at this level in Government and who is responsible for scientific policy overall to come before committees of Congress to testify; whereas he is now precluded from doing that by virtue of the fact he is considered a part of the President's immediate personal staff and therefore by tradition has not been a vailable for testimony.

Upon receipt by the House of Reorganization Plan No. 2 of 1962 your committee again reviewerl its record and the need for an effective, long-range, national oceanograohic program. After the plan became law, further legislative proposals were considered by your committee in the light of the plan and the proposed structure of the new Office of Science and Technology. After full and careful consideratios by the Subcommittee on Oceanography of your committee, a clean bill, H.R. 12601, was diafted and introduced by the acting chairman of the subcommittee, Hon. John D. Dingell, under date of July 18, 1962. Your committee believes the provisions of this bill are fully consonant 
with the oft-asserted goals of both the executive branch and the Congress. Your committee believes that it sets forth, in positive terms, a mechanism within the framework of the Office of Science and T'echnology by which a stated national program in oceanography might be established and maintained, with effective focusing of responsibilities among the departments to the President and to the Congress.

At the same time, H.R. 12601 will permit the high degree of flexibility that a broad, complex and long range program, involving a variety of scientific disciplines, requires.

\section{COST OF THE LEGISLATION}

Since this bill simply describes certain responsibilities to be exercised by the Office of Science and Technology in regard to the establishment of a national oceanographic program, coordination of the activities of the various departments and agencies, and requirements for reporting to Congress, the only cost involved in the bill itseif is the salary of the authorize Assistant Director for Oceanography, i.e., $\$ 19,000$ per annum. Any other expense in connection with the program would be pursuant to the already enacted provisions of the Reorganization Pian No. 2 of 1962.

\section{THE AMENDMENTS}

The amendments to this bill, adopted by your committee, are essentially clarifying or technical in nature.

The expression in the second paragraph of subsection 2(a) with regard to the implementation of the national program, "by both "in-house' and contract research," was considered as being inappropriate in a statement of policy. The bill is reported with the expression deleted.

Subsection 3(c) of the original bill provides that in establishing the national program of oceanography and in revising such program the Office of Science and Technology is required to consult with all interested departments, agencies, and instrumentalities of the United States, "as well as capable nongovernmental institutions and industries were appropriate." It is the clear intent that all sources of knowledge, assistance and guidance be called upon in the national effort. Therefore, to avoid any misunderstanding, the word "nongovernmental," appearing on page 3 , lines 3 and 4 , has been amended to read "nonFederal," so as to make it perfectly clear that our splendid State institutions and others that are supported in whole or in part by some non-Federal governmental entity are to be called upon to contribute to the national program.

On page 4, lines 7 and 8, the words "United States" are inserted in lieu of the words "Federal Government."

In the definition of the term "oceanography" your committee thought it desirable to include "geological" data with the other types of data specifically mentioned. As elsewhere stated in this report, it is the intent of this bill that the national oceanographic program should embrace all scientific fields relevant to the oceanic environment. This amendment merely amplifies your committee's intention. 
The insertion of a comma on page 4 , line 16 , between the words "meteorological" and "climatological" is to correct a typographical error.

\section{DEPARTMENTTAL REPORTS}

As heretofore noted, H.R. 12601 is a clean bill which supersedes H.R. 4276. H.R. 12601 reflects the conchusions of your committee on the basis of extensive hearings held on H.R. 4276 and other aspects of the problem of establishing and maintaining a national program of oceanography, as well as careful consideration by your committee of S. 901 is passed the Senate and referred to your committee.

There are hereafter set forth the departmental reports on H.R. 4276 and S. 901.

\section{Department of Health, Education, and Welfare,} June 26, 1961.

Hon. Herbert C. Bonver,

Chairman, Committee on Merchant Marine and Fisheries, House of Representatives, Washington, D.C.

Dear Mr. Chatrman: This letter is in response to your request of February 15, 1961, for a report on H.R. 4276, a bill to expand and develop the aquatic resources of the United States including the oceans, estuaries, and rivers, the Great Lakes and other inland waters, to enhance the general welfare, and for other purposes.

The bill would establish the National Oceanographic Council, composed of the Secretaries of the Treasury, Defense, Interior, Commerce, and the Chairman of the Atomic Energy Commission, and the Director of the National Science Foundation, among whom the President is to appoint the Chairman; direct the Council to establish a National Oceanographic Data Center or centers, and a National Instrumentation Test and Calibration Center; and assign their functions. The Council is directed to develop long-range plans for research, development, studies, and survers of aquatic environment and to coordinate the efforts of Federal agencies; the Council is authorized to delegate any of its functions to any Federal agency head and to provide for full utilization of Federal agencies' facilities and personnel. In addition, the bill authorizes and directs the Smithsonian Institution to conduct specific taxonomy programs and authorizes necessary appropriations.

This Department is a member of the Interagency Committee on Oceanngraphy. Our interests in oceanography are in consideration of the importance of the rast estuarine and inshore ocean waters and areas as a future major resource for municipal, industrial, and recreational water supplies and our attendant concern as to their use for disposal of municipal and industrial wastes and the berthing of nuclear-powered ships. Tie are similarly concerned with the use of selected areas in the open neean for the disposal of radioactive wastes and the use of the ocean fishery rasources as they rclate to the health of the people of the Cnited States and of the world's underdeveloped comntries which this Nation is aiding.

If a National Oceanographic Council is established, we suggest that, in recognition of our interests outlined above, the Council's composition be modified to include the Secretary of this Department. We contemplate actively contributing to the operation, and utilizing the 
facilities, of the already established National Oceanographic Data Center.

With the exception of the suggested modification, we defer to the appropriate agencies as to the desirability and advisability of enactment of the specific provisions of H.R. 4276 .

We are advised by the Bureau of the Budget that there is no objection to the presentation of this report from the standpoint of the administration's program.

Sincerely yours,

(Signed) Abraham Ribicoff,

Secretary.

Department of the Navy, OfFice of the Secretary, Washington, D.C., May 26, 1961.

Hon. Herbert C. Bonner, Chairman, Committee on Merchant Marine and Fisheries, House of Representatives, Washington, D.C.

My Dear Mr. Chairman: Your request for comment on H.R. 4276, 87th Congress, a bill to expand and develop the aquatic resources of the United States including the oceans, estuaries, and rivers, the Great Lakes and other inland waters, to enhance the general welfare, and for other purposes, has been assigned to this Department by the Secretary of Defense for the preparation of a report thereon expressing the views of the Department of Defense.

The purpose of the bill is as stated in the title.

The Department of Defense subscribes to the objectives of this bill and indeed recognizes the salutary effect which congressional inquiry into the state of the marine sciences has in this area by its emphasis on oceanography as a program required in the national interest. The Department, however, is opposed to the enactment of H.R. 4276 for reasons stated in the subsequent paragraphs.

The bill proposes to establish a National Oceanographic Council to develop long-range plans for and to coordinate the efforts of the Government in the marine sciences. There is already in existence an Interagency Committee on Oceanography, established in January 1960 by the Federal Council for Science and Technology in recognition of the fact that oceanography, is, indeed, an area which requires emphasis and support at the highest level. The Interagency Committee on Oceanography has effectively provided the coordinating mechanism among Government agencies engaged in oceanographic activities for the development of a meaningful national program. Its mission is similar to that which the bill proposes for the National Oceanographic Council and includes, additionally, the very vital function of coordinated budget planning so as to recommend to the Council the level of funding required each year to support the program. Basically, the Interagency Committee on Oceanography develops an annual program incorporating its best judgment as to balance and emphasis in terms of both long-range scientific needs, requirements of Government agencies and fiscal resources.

The membership of the Committee comprises those Federal agencies which have the major interests in Federal oceanographic programs. Its working panels, organized to consider each of the areas highlighted in the bill, include members from all of the Federal agencies engaged in 
the marine sciences. In addition, the scientific community is represented both within the Committee and in its several paneis by the National Academy of Sciences.

In his letter to the presiding officers of the Senate and House on March 29, the President of the United States recommended a $\$ 97$ million fiseal year 1962 national oceanographic program. The Interagency Committee on Oceanography served as the focus for the formulation of this program. This program provides a substantial growth over the $\$ 55$ million level of effort in fiscal year 1961.

The bill proposes to establish a National Oceanographic Data Center. The National Oceanographic Data Center is an existing organization. It was dedicated in its new surroundings at the Naval Weapons Plant on January 16, 1961. The NODC is a distinet Federal activity, operating under a formal interagency agreement and sponsored by the Department of the Navy, the Department of Interior, the Department of Commerce, the National Science Foundation, and the Atomic Energy Commission. Its administration is handled by the Hydrographer of the Navy who receives technical and policy guidance from an advisory board representing the sponsors as well as the scientific community through membership of the National Academy of Sciences.

The bill proposes to establish a National Instrumentation Test and Calibration Center and to provide for the establishment of oceanographic standards. The Interagency Committee on Oceanography is presently actively considering the requirements and needs for such a center, its method of operation, and, in consultation with the National Bureau of Standards, the setting of primary operational standards for instruments and measurements. Until a determination of need is clearly outlined and until a determination of the most suitable method of operation is made, the Department believes that the establishment of the center or a predetermination of its character as a national organization is undesirable.

This report has been coordinated within the Department of Defense in accordance with procedures prescribed by the Secretary of Defense.

The Bureau of the Budget advises that, from the standpoint of the administration's program, there is no objection to the presentation of this report for the consideration of the committee.

Sincerely yours,

$$
\text { (Signed) ROBERT E. M. WARD, }
$$

Rear Admiral, U.S. Navy, Chief of Legislative Affairs

(For the Secretary of the Navy).

Hon. Herbert C. Bonner,

The Secretary of Commerce,

Washington, D.C., May 29, 1961.

Chairman, Committee on Merchant Marine and Fisheries, House of Representatives, Washington, D.C.

Dear Mr. Chairman: This is in response to your letter of February 15, 1961, requesting the views of this Department on H.R. 4276, a bill to expand and develop the aquatic resources of the United States including the oceans, estuaries, and rivers, the Great Lakes and other inland waters, to enhance the general welfare, and for other purposes. 
This bill would establish the National Oceanographic Council, composed of the Secretary of the Treasury, the Secretary of Defense, the Secretary of the Interior, the Secretary of Commerce, the Chairman of the Atomic Energy Commission, and the Director of the National Science Foundation. The Council would be required to develop long-range plans for research, development, studies, and surveys of the aquatic environment, and coordinate the efforts of all Government agencies in the field of oceanography. The Council would be directed to establish a National Oceanographic Data Center, whose functions would be to (1) acquire, assemble, process, and disseminate all scientific and technological oceanographic and related environmental data; (2) conduct research and other projects within the fields of its activities for any department, agency, or instrumentality of the United States on a cost reimbursable basis; and (3) exchange or sell, on a cost reimbursable basis, such data, publications, or other information of the center as the Council deems to be in the public interest.

The Department of Commerce does not favor enactment of H.R. 4276.

The President has recommended a coordinated national program for oceanography to the Congress, which contemplates a virtual doubling of the fiscal year 1961 program. The expanded activities of the various Government agencies under this program can and will be adequately coordinated by the Interagency Committee on Oceanography, a subcommittee of the Federal Council for Science and Technology, which is already performing most of the functions that would be exercised by the proposed National Oceanographic Council.

The National Oceanographic Data Center, located in the Navy Hydrographic Office and supported by agencies which have oceanographic programs, will begin its first full year of operation in 1962. This data center is presently collecting and utilizing information similar to that which would be acquired and studied by the data center provided for in the bill. Under the President's program, the amount recommended for activities of the National Oceanographic Data Center for fiscal year 1962 is almost double that of the fiscal year 1961 program.

For the above reasons, this Department believes that enactment of legislation along the lines of H.R. 4276 is unnecessary at the present time.

The Bureau of the Budget advises there is no objection to the submission of this report from the standpoint of the administration's program.

Sincerely yours,

Edward Gudeman, Under Secretary of Commerce. 


\section{Departanent of the Interior, OfFice of the Secretary, Washington, D.C., June S, 1961.}

Hon. Herbert C. Bonner,

Chairman, Committee on Merchant Marine and Fisheries, House of Representatives, II ashington, D.C.

Dear Mr. Bonner: Your committee has requested a report on H.R. 4276, a bill to expand and develop the aquatic resources of the United States including the oceans, estuaries, and rivers, the Great Lakes and other inland waters, to enhance the general welfare, and for other purposes.

This Department has a vital interest in the field of oceanography. We are sympathetic to the objective of this proposal; however, we do not recommend the enactment of the bill for reasons hereafter stated.

This bill, which is broad in scope, would be cited as the "Oceanographic Act of 1961." It provides for the appointment of a sevenmember National Oceanographic Council. That Council would be required to establish a National Oceanographic Data Center or centers, the functions of which would be to acquire and disseminate scientific and technological oceanographic and related environmental data, to conduct research and other projects for any department or agency, and to exchange or sell such data and information as the Council considers to be in the public interest. The Council would be required to establish primary standards of oceanographic measurements. It would be required also to establish a National Instrumentation Test and Calibration Center. The Council would be required to develop long-range plans for research, development, studies, and surveys of aquatic environments, and to coordinate the efforts of the departments and agencies of the Government of the United States. Annual reports would be submitted to the Congress by the Council. 'The bill contains provisions concerning the supplying of vessels by the United States to governmental or nongorernmental departments or agencies. It would authorize the Smithsonian Institution to construct additional taxonomic facilities to establish a program for the recruitment, training, and placement of taxonomists, and the making of grants to qualified scientists and institutions.

Most of the objectives prescribed in this bill can be accomplished pursuant to existing authority. The Interagency Committee on Oceanography, a committee of the Federal Council on Science and Technology, has been an effective agent for closer cooperation within Government departments. Also, because existing authority allows for the funding of a national oceanographic program, and existing governmental agencies can effectively coordinate such a program, there is no need for another Oceanographic Council, as specified in H.R. 4276.

Concerning section 3 of the bill that would authorize establishment of a National Oceanographic Data Center, it should be noted that such a center is already in existence, and is under the administrative control of the U.S. Navy Hydrographic Office. It receives direction from a special advisory board.

The need for a National Instrumentation Test and Calibration Center, as prescribed by section 5, is worthy of some consideration; however, we believe this provision does not justify an enactment on 
this subject at present. Many of our needs in this field are now being met by the use of facilities in the National Bureau of Standards. Also, private companies that are qualified to test and repair specialized instruments are of assistance in this matter. These are matters that warrant and are receiving attention by the Federal Council and the Interagency Committee on Oceanography.

We agree with the intent of section 9 which authorizes expansion of activities of the Smithsonian Institution. In this connection, it should be noted, however, that the Bureau of Commercial Fisheries has responsibilities for taxonomic research on fishes to meet specific objectives of the national oceanographic program. Our interpretation of this section, therefore, is that additional authority would be given to the Smithsonian Institution without restricting the activities of the Bureau of Commercial Fisheries or other agencies that have requirements to sponsor taxonomic research.

A coordinated and intensified program for oceanography has been recommended by the President in his recent message to the Senate and House of Representatives. We believe that, if adopted, this program will provide a balanced and effective use of our overall resources available for oceanography. We believe the adoption of the President's program will not require additional legislation.

We wish to emphasize, notwithstanding our recommendations on this bill, our great interest in the subject of oceanography and our desire that this form of research proceed efficiently and advantageously in the national interest. Four Bureaus of this Departmentthe Bureau of Commercial Fisheries, Bureau of Sport Fisheries and Wildlife, Bureau of Mines, and the Geological Survey-are directly concerned with programs of research in the field of oceanography. We are prepared to contribute our share, to the extent that funds may be appropriated, toward accomplishment of the objectives of oceanographic research.

The Bureau of the Budget has advised that there is no objection to the presentation of this report from the standpoint of the administration's program.

Sincerely yours,

Frank P. Briggs, Assistant Secretary of the Interior.

Hon. Herbert C. Bonner,

The Secretary of the Treasury, Washington, April 28, 1961.

Chairman, Committee on Merchant Marine and Fisheries, House of Representatives, Washington, D.C.

My Dear Mr. Chatrman: Reference is made to your request for the views of this Department on H.R. 4276, to expand and develop the aquatic resources of the United States including the oceans, estuaries, and rivers, the Great Lakes and other inland waters, to enhance the general welfare, and for other purposes.

The bill would create a National Oceanographic Council which would be given broad authority apparently designed to permit the Council to direct the national oceanographic effort. 
'The President in his letter to the Speaker of the House dated March 29, 1961, outlined an extensive national program in oceanography including the construction of ships, shore facilities, and data centers; conduct of basic and applied oceanographic research; training of oceanographers; and surveys of the oceans. The letter stated that the program would require the combined efforts of our institutions, both public and private, and the coordinated efforts of many Federal agencies. Howerer, the letter did not recommend a new governmental organization such as would be established by the bill, but envisaged that the program would be executed by the agencies concerned under present organizational arrangements.

In the circumstances, the Department would be opposed to the enactment of the bill.

The Department has been advised by the Burean of the Budget that there is no objection from the standpoint of the administration's program to the submission of this report to your committee.

Very truly yours,

ROBERT H. KNIGHT, Acting Secretary of the Treasury.

\section{Comptroller General of the United States,} Washington, March 28, 1961.

Hon. Herbert C. Bonner,

Chairman, Committee on Merchant Marine and Fisheries, House of Representatives.

Deatr Mr. Chairman: Your letter of February 15, 1961, requests our comments on H.R. 4276. The purpose of the bill is to expand and develop the aquatic resources of the United States and the bill would establish a National Oceanographic Council.

We have no special information concerning the subject matter of the bill and, therefore, we make no recommendation with respect to its enactment. However, concerning section 10 of the bill, under existing law (31 U.S.C. 67 and 72 ) we have the authority to initially audit all expenditures from the Treasury except where otherwise specifically provided by law. Also, under existing law we have the right to examine the books and records of certain Government contractors. See, for example, Public Law 245, 82d Congress, 65 Stat. 700 . The provisions of section 10 would appear to have the effect of restricting this existing authority in the case of expenditures of $\$ 50,000$ or more. We do not feel our existing authority should be so restricted. Further, in view of the increase in grant programs over the last several years we feel that in order to determine whether grant funds have been expended for the purpose which the grant was made the grantee should be required to keep records which would fully disclose the disposition of such funds. We also feel that the agency making the grant as well as the General Accounting Office should be permitted to have access to the grantee's records for the purpose of audit and examination. Consistent with the foregoing, we suggest that section 10 be changed to read as follows:

"(a) Each recipient of assistance under section 9(a)(3) of this Act shall keep such records as the Secretary of the Smithsonian Institution shall prescribe, including records which fully disclose the amount and the disposition by such recipient of the proceeds of such assistance, the 
total cost of the project or undertaking in connection with which such assistance is given or used, and the amount and nature of that portion of the cost of the project or undertaking supplied by other resources, and such other records as will facilitate an effective audit.

"(b) The Secretary of the Smithsonian Institution and the Comptroller General of the United States, or any of their duly authorized representatives, shall have access for the purpose of audit and examination to any books, documents, papers, and records of the recipient that are pertinent to assistance received under section 9(a)(3) of this Act."

In administering the above provision we do not contemplate making a detailed examination of the books and records of every recipient of a grant, or even a major part of them. However, selective checks may be made to provide reasonable assurance that grant funds are being properly applied or expended.

Sincerely yours,

Joseph Camprell, Comptroller General of the United States.

\section{U.S. Atomic Energy Commission, June $6,1961$.}

Hon. Herbert C. Bonner,

Chairman, Committee on Merchant Marine and Fisheries, House of Representatives.

Dear Mr. Bonner: The Atomic Energy Commission is pleased to have this opportunity to comment on H.R. 4276, a bill to expand and develop the aquatic resources of the United States.

The Commission does not believe that the establishment by this bill of the National Oceanographic Council and Data Center is needed. Some months ago the Departments of the Navy, Commerce, and Interior, the National Science Foundation, and the Atomic Energy Commission, entered into an interagency agreement providing for the establishment of a National Oceanographic Data Center, to be located within the U.S. Navy Hydrographic Office, and the creation of a National Oceanographic Data Center Advisory Board. The Advisory Board consists of one member from each of the following agencies: Navy Hydrographic Office, Coast and Geodetic Survey, Bureau of Commercial Fisheries, National Science Foundation, Weather Bureau, Office of Naval Research, and the Atomic Energy Commission. The agreement states that the National Academy of Sciences will be invited to name two nonvoting members to sit in with the Advisory Board. This interagency Data Center will, pursuant to the agreement, (a) receive, compile, process, and preserve oceanographic data submitted to it, (b) acquire ocenographic data from domestic and foreign sources, $(c)$ establish procedures for assuring that the accuracy and quality of the data in its repository meets the criteria established by the Advisory Board, $(d)$ prepare data summaries and tabulations, indexes, and other information, and (e) perform certain other useful functions in regard to oceanographic data. The Center's activities will not duplicate those of the Weather Bureau, Coast and Geodetic Survey, Smithsonian Institution, or other agencies. In the Commission's opinion, the Data Center and the companion Advisory Board recently inaugurated under the interagency agreement are 
well organized and are capable of effectuating the basic purposes of the bill; the Commission believes they should not be replaced by the Council and Center the bill would establish.

In addition to the preceding general observations, the Commission would like to make these specific remarks: The provision in section 2 of the bill that the members shall be the Secretaries of the named departments, the Chairman of the Atomic Energy Commission, and the Director of the National Science Foundation seems to us to be out of proportion to the fact that these oceanographic activities are, though important, but a relatively small part of the respective programs of each of these agencies; also, we think the chairmanship should rotate and that the Presidential appointment feature is unnecessary. In regard to section 3, conduct of research is not, in our opinion, an appropriate function of the Data Center. The interagency Center will not conduct research. The function specified in section 4, namely, the establishment of primary standards of oceanographic measurements, is also unnecessary in our opinion because the U.S. Bureau of Standards now develops satisfactory standards in this area. Nor do we consider the separate Test and Calibration Center, provided for in section 5, to be needed; the specified testing, calibration, and evaluation work should, in our view, be performed by the National Bureau of Standards.

The Bureau of the Budget has advised that there is no objection to the presentation of this report from the standpoint of the administration's program.

Sincerely yours,

(Signed) R. E. Hollingsworth, Deputy General Manager.

Executive Office of the President,

Bureau of the Budget, Washington, D.C., May 9, 1961.

Hon. Herbert C. Bonner, Chairman, Committee on Merchant Marine and Fisheries, House of Representatives, Washington, D.C.

My Dear Mr. Chairman: This is in reply to your letter of February 15, 1961, requesting the comments of this office with respect to H.R. 4276, a bill to expand and develop the aquatic resources of the United States including the oceans, estuaries, and rivers, the Great Lakes and other inland waters, to enhance the general welfare, and for other purposes.

This bill would establish a National Oceanographic Council to develop and coordinate a long-range program in oceanography. Among its responsibilities the Council would establish a National Oceanographic Data Center and a National Instrumentation Test and Calibration Center.

In his letter of March 29, 1961, to the Speaker of the House, the President outlined a national program to strengthen oceanography on a long-term basis. He announced that additional funds were being requested for a number of agencies in 1962 to provide almost a doubling of the current year's level of effort in oceanography.

This national program was developed under the auspices of the Interagency Committee on Oceanography of the Federal Council for Science and Technology and through coordination of the plans and 
programs of the Federal agencies concerned with oceanographic research and ocean surveys. Significant progress in coordinating the efforts of several agencies has been achieved by the Interagency Committee on Oceanography as illustrated by the oceanographic program recommended by the President. This, in turn, is part of a broader integration of scientific activities undertaken by the Federal Council for Science and Technology.

Regarding the Council proposed in H.R. 4276, the Bureau generally considers it undesirable to have interagency arrangements for the management of common activities fixed by statute in view of the necessity for providing flexibility to meet the unforeseen needs of the future and for assuring clear Presidential authority over the management of the executive branch. This is particularly true in the case of national programs in science, such as oceanography, where the pattern of organization over the long term is still evolving and is under active study.

With regard to the establishment of the National Oceanographic Data Center, this Center has already been established under those agencies involved in oceanography and, accordingly, the provisions of the bill regarding this Center are not necessary.

Consideration is still being given to the need for and nature of a National Instrumentation Test and Calibration Center or centers. Should such a center or centers prove desirable, they can be established under existing legislative authority.

Finally, with regard to authorizing the Smithsonian Institution to initiate a program in oceanography, it should be noted that the Smithsonian Institution is already authorized to conduct such a program. Further study of the appropriate role of the Institution in this field is being conducted at present.

For the reasons given above, enactment of H.R. 4276 would not be consistent with the administration's objectives.

Sincerely yours,

Phillip S. Hughes, Assistant Director for Legislative Reference.

\section{National Sctence Foundation, OfFICE OF THE DiRector, Washington, D.C., July 18, 1961.}

Hon. Herbert C. Bonner,

Chairman, Committee on Merchant Marine and Fisheries, House of Representatives, Washington, D.C.

Mr Dear Mr. Bonner: This is in further reply to your recent request for the comments of the National Science Foundation on H.R. 4276, entitled the "Oceanographic Act of 1961."

H.R. 4276 would establish a National Oceanographic Council, composed of representatives of six Federal departments or agencies, to develop long-range plans for oceanographic resarch and to coordinate the efforts of the various agencies and departments of the Government in this regard. H.R. 4276 would also direct the establishment of a National Oceanographic Data Center or centers and a National Instrumentation Test and Calibration Center, require that title to vessels supplied by the United States be returned to the United States 
upon completion or other termination of the purpose for which the vessel has been supplied and authorize the Secretary of the Smithsonian Institution to expand the taxonomic facilities of the Institution with particular emphasis on the taxonomy of marine organisms.

H.R. 4276 is aimed at insuring that the United States has a strong oceanographic program. TVe are in complete accord with this objective. In this connection, as you know, the President, on March 29, 1961, transmitted to the Congress his recommendations with respect to the appropruation of funds for fiscal year 1962 to carry on the Federal effort in oceanography. The total amount requested for all Federal agencies is approximately $\$ 97.5$ million. Of this amount, nearly $\$ 20$ million is for the programs of the National Science Foundation. We believe that if the amounts requested by the President for the Foundation for fiscal year 1962 for support of oceanographic research activities are provided by the Congress, they will enable the Federal Government to continue to strengthen its oceanographic research activities in a sound manner.

In addition, one of the primary objectives of H.R. 4276 is to assure that there is a continuing national policy and program for carrying out the Nation's oceanographic eflort. Coordination of the activities of the Federal agencies in this area is presently the responsibility of the Federal Council for Science and Technology, whose Chairman is the Special Assistant to the President for Science and Technology. It is, of course, important, in the carrying out of the national program, that full information be available with respect to the status of the national effort, both public and private, and the needs in particular areas of this endeavor. The National Science Foundation, in carrying on its support of basic research in oceanography and related fields, keeps in close touch with oceanographic research activities throughout the world. In this connection, we are planning to issue, at appropriate intervals, reports on the status of oceanographic research together with assessments, as appropriate, of national needs in this area.

We are deeply mindful of the importance of oceanographic research to the national welfare and are prepared to cooperate in any way possible to assure that the occanographic effort of the United States is second to none.

With respect to the proposed Data Center, such a center has been established within the Hydrographic Office of the Department of the Navy, funded jointly by the various Federal agencies concerned with oceanographic research activities. We believe that this arrangement is proving to be quite effective.

We feel that the matter of establishing a National Instrumentation Test and Calibration Center should be given serious consideration. However, we are not certain that a separate organizational arrangement should be established for this purpose but believe that such a center might usefully be established within one of the existing Federal agencies.

With respect to the matter of vessels supplied by the United States, it has been our general riew that where such vessels are provided to educational or other nonprofit institutions for research purposes, the considerations of allowing the grantee to retain title outweigh the advantages to be gained should title to the vessel be retained by the United States. On the other hand, we agree that, as a general rule, such vessel should be utilized only for the research purposes for which they have been provided and that, when they are no longer being used 
for such purposes, the vessels should be returned to the United States. Similarly, such vessels should be available for Government use in time of emergency.

The matter of increased taxononic facilities at the Smithsonian Institution we believe is one that the Institution is best qualified to assess.

The Bureau of the Budget has advised us it has no objection to the submission of this report.

Sincerely yours,

(Signed) Alan T. Waterman,

Director.

Smithsonian Institution, Washington, D.C., June 23, 1961.

Hon. Herbert C. Bonner,

Chairman, Committee on Merchant Marine and Fisheries,

House of Representatives, Washington, D.C.

Dear Mr. Bonner: Thank you for your letter of February 15, 1961, asking for the comments of the Smithsonian Institution on H.R. 4276, a bill to expand and develop the aquatic resources of the United States including the oceans, estuaries, rivers, the Great Lakes, and other inland waters, to enhance the general welfare, and for other purposes.

The Smithsonian Institution is greatly interested in the field of oceanography and welcomes the opportunity to share in the expansion of research now going on in that important area of scientific knowledge. For more than a century, since its inception in 1846, the Smithsonian Institution has fostered and encouraged the increase and diffusion of knowledge in the realm of the natural sciences. Its sustained interest in oceanography has been evidenced by the many oceanographic expeditions in which it has participated and in the continuing related taxonomic activities of its highly specialized staff of scientists.

It is believed that statutory authority already exists for the Smithsonian Institution generally to engage in oceanographic activities. This authority is embodied in the act of August 10, 1846 (9 Stat. 105) and in the act of March 3, 1879 (20 Stat. 397).

In regard to the provisions of H.R. 4276, the following comments are offered:

Reference, section 2: The establishment of a high-level National Oceanographic Council seems unnecessary in view of existing administrative arrangements to coordinate national programs assigned to various agencies by law. However, if such a Council were to be created, it is suggested that the Secretary of the Smithsonian Institution be named to membership.

Reference, section 9(a)(1): The construction of additional taxonomic facilities is not required immediately. At least during the initial stages, activities incident to the expansion of the program of collecting aquatic and marine organisms could be accommodated within the facilities of the additional west wing of the Natural History Building.

Reference, section 9(a)(2): The Smithsonian Institution is not staffed to recruit, train, and place taxonomists in such number as may be required to classify fishes and marine invertebrates collected in carrying out the purposes of the bill. We suggest that this responsi- 
bility be left with universities and other agencies which are presently handling such activities.

Reference, section 9(a): By provision of the act of March 3, 1879, referred to above, the Smithsonian Institution has been designated as the official repository of the governmental coliections of "rocks, minerals, soils, fossils, and objects of natural history, archaeology, and ethnology." However, it would be useful to redefine repository responsibility in this area and to assure that the collection and preservation of marine organisms is given proper emphasis in the expansion of oceanographic activities recently recommended by the President. We believe that repository responsibility of the Institution can be affirmed by administrative action and we shall continue our efforts in that direction. 'This would assure that specimens collected in the course of the various phases of oceanographic research which are no longer needed for investigations in progress would not be lost but would ultimately be available for continuing taxonomic study.

The Bureau of the Budget advises that there is no objection to the submission of this report to the Congress.

Sincerely yours,

Leonard Carmichael, Secretary.

Hon. George P. Miller,

National Academy of Sciences,

National Research Council, Committee on OCeanography, Washington, D.C., July 27, 1961.

Room 506, Old House Office Building, Washington, D.C.

Dear Congressman Miller: At my request, Sumner Pike, Milner Schaefer, and Roger Revelle of the National Academy of Sciences' Committee on Oceanography reviewed and prepared comments on H.R. 4276. I wish their findings to be incorporated in my testimony before your Subcommittee on Occanography June 22.

In general, they endorse the concept of a National Oceanographic Council as a means of continuing the long-range development of a coordinated national oceanographic program.

Specifically, they recommend that-

(1) The proposed Council should have an advisory committee made up of leading nongovernmental marine scientists. The members of this committee should be selected from a slate of nominations prepared by the National Academy of Sciences.

(2) The members of the Council should either be Presidential appointees at the time of their appointment to the Council or their appointment to the Council should be submitted by the President to the Senate for confirmation. There should be one member from each of the Federal departments and independent agencies concerned with oceanography.

(3) In addition to those Council members identified in H.R. 4267 , the Council should have a member from the Department of Health, Education, and Welfare, and the Department of State. These departments have a substantial stake in a coordinated national oceanographic program. The Public Health Service is actively studying pollution problems in coastal waters and it is 
supporting research in marine biology. The Office of Education in HEW is concerned with the education and training of oceanographers. The State Department has cognizance of various international fisheries commissions which do oceanographic research. Moreover, the national oceanographic program will require international cooperation and the help and participation of the State Department will be needed.

(4) The prime mission of the Council should be to develop and coordinate a cooperative interagency national oceanographic program. We believe that the Council can be particularly effective in maintaining a balance between applied research, basic research, facilities, ships, survey operations, international cooperation, and education.

(5) A substantial annual appropriation should be authorized to the Council to enable it to better develop a balanced program by direct transfer of such funds to various agencies for their authorized purposes.

(6) Adequate provision should be made for a small qualified staff for the Council headed by a highly qualified scientist.

(7) The Council should report on the progress of the national oceanographic program directly to the President and via the President to the Congress.

(8) The Council and its staff should be located administratively within the Executive Office of the President.

I appreciate this opportunity of bringing these views on H.R. 4276 to your attention.

Sincerely yours,

RichaRd C. VILler

(For Athelstan Spilhaus, Acting Chairman).

\section{Comptroller General of the United States,} Washington, October 16, 1961.

B-140845.

Hon. Herbert C. Bonner,

Chairman, Committee on Merchant Marine and Fisheries, House of Representatives.

Dear Mr. Chairman: Further reference is made to your letter of August 4, 1961, acknowledged on August 8, requesting the comments of the General Accounting Office concerning S. 901, 87th Congress, 1st session, entitled "An Act to advance the marine sciences, to establish a comprehensive 10-year program of oceanographic research and surveys, to promote commerce and navigation, to secure the national defense, to expand ocean, coastal, and Great Lakes resources, to authorize the construction of research and survey ships and laboratory facilities, to expedite oceanographic instrumentation, to assure systematic studies of effects of radioactive materials in marine environments, to enhance the public health and general welfare, and for other purposes."

The general purpose of S. 901 is a matter of policy for the determination of the Congress. However, in the consideration of the bill, we recommend the following clarifications:

Section 8(a) of the proposed legislation authorizes appropriations to the Coast and Geodetic Survey as are necessary for the construction of eight survey ships. The Coast and Geodetic Survey has requested funds in the amount of $\$ 9,425,000$ to be appropriated in fiscal year 
1962 for one oceanographic surveying vessel under its existing ship construction legislation (33 U.S.C. 883i). The Bureau has also proposed in its 1962 budget justifications a program for construction of seven additional oceanographic ships and it expects to request the necessary funds during fiscal years 1963 through 1965 . It is not clear whether the eight ships required to be constructed by section 8 (a) of the bill are the same as or in addition to the eight ships included in the Coast and Geodetic Survey's proposed oceanographic program.

Section 8(b) does not place any limitation on the cost of operating new Coast and Geodetic Survey ships, while a 10-year limitation is imposed on the National Science Foundation by section 4(b) and annual limitations are imposed on the Bureau of Commercial Fisheries by section $6(\mathrm{~b})$ and on the Navy by section 14 . We recommend clarification on this point.

Section 8(i) imposes a qualification that any person receiving training or education at the expense of the Department of Commerce must agree to continue employment in the Department for a period of not less than 3 years for each year of training received. However, the bill does not contain a similar qualification for training and educational programs of other agencies. In view thereof, and since we are unable to ascertain whether such a limitation was intended for other agencies, we recommend that this phase of the matter be clarified.

By making oceanographic research one of the primary duties of the Coast Guard, under this bill, it appears that under the authority of 14 U.S.C. 92 (d) the Secretary of the Treasury could then construct vessels for the exclusive purpose of oceanographic research. It is not clear, however, whether the Coast Guard was intended to have this additional ship construction authority since the bill would place a monetary limitation on the amount of scientific equipment that may be installed on each Coast Guard vessel assigned oceanographic research duties. Accordingly, we recommend that the bill clearly indicate whether this additional ship construction authority is intended to be granted to the Coast Guard.

We suggest that the term "operating costs" on page 39 , line 20 , be clarified to indicate the actual costs intended to be included. We have been advised informally by the Department of the Navy that they overlooked this provision in their review of the prior bill and that careful consideration would be given therto in their study of the present bill. We observe that operating eosts of ships are also referred to in various other sections of the bill without indication of the costs intended to be included, e.g., line 23, page 8 ; lines 3 and 5 , page 16 ; and line 18 , page 24 .

Sincerely yours,

\section{Joseph Campbell, Comptroller General of the United States.}

Departaent of the Navy, OfFice of THE SECRETARY, Washington, D.C., December 6, 1961.

Hon. Herbert C. Bonver, Chairman, Committee on Merchant Marine and Fisheries, House of Representatives, Washington, D.C.

My Dear Mr. Chairman: Your request for comment on S. 901, an act to advance the marine sciences, to establish a comprehensive 
10-year program of oceanographic research and surveys, to promote commerce and navigation, to secure the national defense, to expand ocean, coastal, and Great Lakes resources, to authorize the construction of research and survey ships and laboratory facilities, to expedite oceanographic instrumentation, to assure systematic studies of effects of radioactive materials in marine environments, to enhance the public health and general welfare, and for other purposes, has been assigned to this Department by the Secretary of Defense for the preparation of a report thereon expressing the views of the Department of Defense.

The purpose of the proposed act is as stated in the title.

The Department of Defense subscribes to the objectives of this act and indeed recognizes the stimulating effect which congressional inquiry into the state of the marine sciences has had in this area by its emphasis on oceanography as a program vital to the national interest.

The bill proposes to establish a Division of Marine Sciences in the National Science Foundation in which an interagency committee would be formed to develop and encourage a continuing national policy and program for the promotion of the marine science. There is already in existence an Interagency Committee on Oceanography, established in January 1960 by the Federal Council for Science and Technology in recognition of the fact that oceanography is, indeed, an area which requires emphasis and support at the highest level. The Interagency Committee on Oceanography has effectively provided the coordinating mechanism among Government agencies engaged in oceanographic activities for the development of a meaningful national program. Its mission is similar to that which the bill proposes for the National Science Foundation Division and includes, additionally,

the very vital function of coordinated budget planning so as to recommend to the Council the level of funding required each year to support the program. Basically, the Interagency Committee on Oceanography develops an annual program incorporating its best judgment as to balance and emphasis in terms of both long-range scientific needs, requirements of Government agencies and fiscal resources.

The membership of the Committee comprises those Federal agencies which have the major interests in Federal oceanographic programs. Its working panels, organized to consider each of the areas highlighted in the act, includes members from all of the Federal agencies engaged in the marine sciences. In addition, the scientific community is represented both within the Committee and in its several panels by the National Academy of Sciences.

Those aspects of S. 901 which relate to the specific delineation of development items, shipbuilding tonnages, and money authorizations emphasize areas which will see many modifications over the years. Such specific delineation may, in fact, be restrictive to a program which fundamentally should be sufficiently flexible to accommodate program reorientation resulting from changes in agency requirements and technological advances as they occur and appear warranted.

Section 21 (e) of S. 901 would apparently require that title to all patents on inventions arising out of research performed under the authority of the act be vested in the Government. The broad question of the proper disposition of patent rights in inventions made under Federal contracts and grants is presently before the appropriate 
committees of the Congress, and it is believed undesirable to deal with such a complex and far-reaching problem in a piecemeal fashion. Moreover, it is believed that mandatory application of the principle of section 21(e) in all cases would only hamper and discourage, and may even impede, the conduct of research and development in oceanography and many other fields having oceanographic application, such as are contemplated in sections $13-16$ of S. 901 .

In summary, the Interagency Committee on Oceanography is accomplishing the objectives which this act seeks to achieve. Therefore, for the reasons stated, the Department of Defense believes that this legislation is not necessary.

This report has been coordinated within the Department of Defense in accordance with procedures prescribed by the Secretary of Defense.

The Bureau of the Budget advises that, from the standpoint of the administration's program, there is no objection to the presentation of this report for the consideration of the committee.

Sincerely yours,

$$
\begin{gathered}
\text { Robert E. M. WARd, } \\
\text { Rear Admiral, U.S. Navy, Chief of Legislative Affairs }
\end{gathered}
$$

(For the Secretary of the Navy).

\section{Departient of Health, Education, and Welfare,} Washington, January 4, 1962.

Hon. Herbert C. Bonver,

Chairman, Committee on Merchant Marine and Fisheries, House of Representatives, Washington, D.C.

Dear Mr. Chatrifan: This is in response to your request for a report on S. 901, a bill to advance the marine sciences, to establish a comprehensive 10-year program of oceanographic research and surveys, to promote commerce and navigation, to secure the national defense, to expand ocean, coastal, and Great Lakes resources, to authorize the construction of research and survey ships and laboratory facilities, to expedite oceanographic instrumentation, to assure systematic studies of effects of radioactive materials in marine environments, to enhance the public health and general welfare, and for other purposes.

As indicated by its title, the bill would establish a broad 10-year program of oceanographic research and surveys through the facilities of existing Federal departments and agencies. It is similar to S. 2692, 86 th Congress, which was introduced to carry out the policy expressed in Senate Resolution 136, passed on July 15, 1959, which, inter alia, commended to the President and to interested agencies the report of the Committee on Oceanography of the National Academy of SciencesNational Research Council, and concurred in a number of recommendations of that Committee which would result in the expansion of basic and applied oceanographic research (in part through the construction of shore facilities), the training of additional oceanographic scientists, the conduct of certain ocean surveys, a revamping and expansion of the Nation's oceanographic research fleet, an investigation of the effects of radioactivity in oceans, and numerous related programs.

In accord with his message on natural resources, in which he indicated his intention "to send to the Congress for its information 
and use in considering the 1962 budget, a national program for oceanography setting forth the responsibilities and requirements of all participating Government agencies," the President, by letter of March 29, presented his program to the Congress. The program outlines the steps necessary to translate into concrete terms the desire of the administration, stated in the natural resources message, "to give concerted attention to our whole national effort in the basic and applied research of oceanography." The proposal is predicated upon the fact that sufficient basic authority already exists in the executive branch to embark upon a national program for oceanography, although existing legislation is not limited in scope to oceanography as such.

For example, section 9 of the bill would authorize the Secretary of Health, Education, and Welfare to award fellowships in oceanography and the marine sciences. However, under title IV of the National Defense Education Act of 1958, the Commissioner of Education is now authorized to award 1,500 fellowships in fiscal 1962 for graduate study in any field for periods of study not in excess of 3 acadenic years. The administration has requested that this authority be increased to 5,000 fellowships and extended indefinitely. Section $4(f)$ of the bill would authorize an appropriation of $\$ 4,800,000$ to the National Science Foundation for a program of fellowships for students not below the senior level of undergraduate school and continuing through up to 4 years of graduate training in marine sciences, and for fellowships and research apprenticeships to graduate students and postdoctoral fellows training to become professional physical, biological, chemical, and geological oceanographers. The National Science Foundation has at present two fellowship programs for graduate students-graduate fellowships and cooperative graduate fellowships. The program of graduate fellowships is designed to offer support to unusually able students to enable them to complete their graduate studies with the least possible delay. The cooperative graduate fellowships differ from the graduate fellowships in that institutions would, in effect, receive funds for fellowship support for individual graduate students of science, mathematics, and engineering whom they have recommended. The Foundation has offered, from fiscal year 1960 funds, about 1,200 fellowships under each of these 2 programs.

The Foundation has broad authority to initiate and support basic scientific research and programs to strengthen scientific research potential. It can now award fellowships for oceanography as part of its broad programs for granting fellowships in a variety of fields to individuals possessing the greatest scientific talent. Moreover, the Foundation can use its authority to make grants in support of basic scientific research to give additional impetus to the development of those sciences, such as oceanography, for which there is a critical need. We understand that, prior to the President's message, the Foundation, in recognition of the need for increased attention to the support of research in oceanography, had added a full-time oceanographer to its program on earth sciences, and had taken other measures to foster oceanographic research and the training of research workers.

In view of the foregoing, the bill would not appear to create any significant new authority in the executive branch to award fellowships, and therefore these portions of it seem unnecessary. However, with respect to the bill's desirability as a whole, we defer to the views of the departments and agencies most closely affected by it. 
Should the bill receive favorable consideration, we recommend that it be amended to provide that nothing in the bill is intended to limit the authority vested in the Secretary or other officials of this Department, or in other officials or agencies of the executive branch, under existing law. In our view, section 11 of the bill might possibly be construed to limit the Department's current authority in the radiation field. In view of the importance of our role in promoting radiological health protection, the amendment is suggested, in event of the bill's enactment, to remove any possible doubt as to the legal basis for the continuation of currently assigned functions.

We are advised by the Bureau of the Budget that there is no objection to the presentation of this report from the standpoint of the administration's program. Sincerely,

(Signed) Wilbur J. Cohen, Assistant Secretary.

Department of State, Washington, August 23, 1961.

Hon. Herbert C. Bonver, Chairman, Committee on Merchant Marine and Fisheries, House of Representatives.

Dear Mr. Chairmax: In your letter to the Secretary of August 4, 1961, you asked for comments concerning S. 901, 87 th Congress, 1st session, the Marine Sciences and Research Act of 1961.

While the Department is in accord with the purposes and intent of the proposed legislation, it is our view that enactment of the bill is unnecessary. This opinion is based upon the fact that the Federal Council for Science and Technology has set up an Interagency Committee on Oceanography, which has developed a sound oceanographic research program for the United States. 'The Interagency Committee on Oceanography has been successful in coordinating the current and planned U.S. activities in this scientific area.

Recently the Department designated the Secretary's science adviser to participate as an observer at meetings of the ICO. This representation sponsors Department consideration of the international features of oceanographic research programs designed by the ICO. The Department has had and will continue to have an interest in securing the conperation of other countries for expeditions and surveys in international and territorial waters.

It is desirable both for foreign relations and for the advancement of knowledge which will be of benefit to mankind that the U.S. efforts in marine science be strengthened. Such strengthening will be achieved by adoption of the expanded national programs in oceanography recommended by the President in his recent messages to the House and the Senate.

The Bureau of the Budget advises that, from the standpoint of the administration's program, there is no objection to the presentation of this report for the consideration of the committee.

Sincerely yours,

Brooks HAYs, Assistant Secretary (For the Secretary of State). 
Smithsonian Institution,

Hon. Herbert C. Bonner,

Washington, D.C., August 15, 1961.

Chairman, Committee on Merchant Marine and Fisheries, U.S. House of Representatives, Washington, D.C.

Dear Mr. Bonner: This letter is in reply to your request of August 4, 1961, for the views of the Smithsonian Institution with respect to $S$. 901 , a bill to advance the marine sciences, to establish a comprehensive 10-year program of oceanographic research and surveys, to promote commerce and navigation, to secure the national defense, to expand ocean, coastal, and Great Lakes resources, to authorize the construction of research and survey ships and laboratory facilities, to expedite oceanographic instrumentation, to assure systematic studies of effects of radioactive materials in marine environments, to enhance the public health and general welfare, and for other purposes.

As has been stated previously, the Smithsonian Institution has had a continuing interest in the biological aspects of oceanography since its establishment, and in the increase and diffusion of such knowledge. Comments on the proposed legislation, however, will be restricted to those sections which directly involve the Smithsonian Institution.

1. Reference: Section 19 (a) and 20(a). Construction of facilities additional to those now made available to the Smithsonian Institution by recent acts of Congress may not be required in the immediate future. The need for future enlargement of these facilities will be conditioned by the scope and growth of this program and the resulting quantity of aquatic and marine organisms received annually by the Institution.

2. Reference: Section 19(b) and 20(b). As to the recruitment and placing of taxonomists, the Smithsonian Institution is not equipped to do this type of personnel work and believes it should be left in the hands of other agencies of the Government which are presently handling these programs.

As to the training of taxonomists, the Smithsonian Institution is qualified and prepared to carry on the advanced training of junior staff members after they have completed their basic training in a university or college of recognized academic standing. The Smithsonian Institution is not a degree-granting organization and is not staffed to render basic training. Other agencies are now engaged in facilitating basic as well as advanced training, and in our opinion they should continue to do so. It is believed preferable that taxonomists receive their basic educational training under the authorized programs of universities and of other Federal agencies.

3. Reference: Sections 19 (c) and 20(c). It is suggested that the words "and/or to contract with" be added following the words "to make grants of funds to" on line 11, page 52 .

4. Reference: Section 19(d). The Smithsonian Institution has cooperated to the extent permitted by available funds and when consistent with its authorized mission with other agencies and organizations. 
5. Reference: Section 20(e). It is suggested that a new section 20(e) be added with wording as follows: "Such appropriation shall be in addition to other appropriations provided to the Smithsonian Institution to carry out its duties under law."

Thank you for the opportunity to comment on this proposed legislation. You are advised that there is no objection to the presentation of this proposed report from the standpoint of the administration's program.

Sincerely yours,

\section{Leoxard Carmichael, Secretary.}

Hon. Herbert C. Boxyer,

Natioxal Acadeiry of Sciexces,

Washington, D.C., August $21,1961$.

Chairman, Committee on Merchant Marine and Fisheries,

House of Representatives, Washington, D.C.

Dear Mr. Bonner: Your letter of August 4, 1961, to President Detler W. Bronk, of the National Academy of Sciences, invites his comments on S. 901, Marine Sciences and Research Act of 1961.

Members of our Committee on Oceanography testified in detail last March on the provisions of the original S. 901, and their testimony appears in the published hearings of that time before the Senate Interstate and Foreign Commerce Committee. The current version of S. 901 contains revisions based on the testimony of those individuals and other's. Although our Committee has not reviewed the new S. 901 in detail, it seems clear that they would consider it an improvement over the original bill, which the Committee is already on record as faroring.

Yours sincerely,

\section{S. D. Conveld, Executive Officer.}

Executive Office of the President, Bureau of the Budget,

Hon. Herbert C. Boxier, Washington, D.C., August 17, 1961.

Chairman, Committee on Merchant Marine and Fisheries, House of Representatives, Washington, D.C.

Dear Mr. Chatruax: This is in response to your request for views and recommendations on S. 901, a bill to advance the marine sciences, to establish a comprehensive 10-year program of oceanographic research and survers, to promote commerce and navigation, to secure the national defense, to expand ocean, coastal, and Great Lakes resources, to authorize the construction of research and survey ships and laboratory facilities, to expedite oceanogranhic instrumentation, to assure systematic studies of effects of radioactive materials in marine environments, to enhance the public health and general welfare, and for other purposes.

Strengthening and promoting the marine sciences, as the bill proposes, are important objectives, but in our judgment, enactment of the bill is not necessary to achieve those objectives for the following reasolns: 
1. As far as can be determined the various agencies engaged in or supporting research in the marine sciences generally appear to have adequate legislative authority to continue or expand their programs in this field. The substantive authority provided by the bil, therefore, would only broadly duplicate existing authority. Legislation to provide additional authority which may be thought necessary by any single agency should be considered in each instance on its own merits (e.g., H.R. 6845 which would give the Coast Guard more general authority to engage in oceanographic activities).

2. The provision of specific money authorizations and program directives in the bill for the various agencies already engaged in oceanographic research programs is so complex and detailed that it could curtail the flexibility which is needed to meet changing requirements and circumstances in the future. It would also complicate the administration of the program by the necessity for extra accounting controls. Long-range plans are of course desirabie to encourage and guide the strengthening of oceanography. However, it is difficult to determine now with any degree of precision what the relative distribution and scope of efforts should be agency by agency and program by program over the long term. Continuing review and readjustment of the national program are necessary to insure a well-balanced effort. Such readjustment should not be dependent on changes in the law as would be required if S. 901 were enacted.

In connection with section 21 (c), it is also considered to be undesirable to fix by statute the details of budget-supporting material to be submitted to the Congress. The Bureau is always willing to prepare special analyses of the budget upon request of concerned committees of Congress, but it is better not to fix the specific nature of such materials in law in order that reports may be responsive to current needs.

3. The establishment of a division of marine sciences in the National Science Foundation with an accompanying interagency divisional committee is considered undesirable in light of the general principle enunciated in Hoover Commission reports and elsewhere that internal agency organization should not be fixed in law, nor should functions be vested by statute in subordinate agency units. Furthermore, the arrangements proposed by the bill seem unnecessary to effect coordination and overall planning of Federal marine science policies and programs since an effective mechanism now exists to accomplish that purpose, viz, the Interagency Committee on Oceanography (ICO) of the Federal Council for Science and Technology. The Federal Council, which is chaired by the Special Assistant to the President for Science and Technology, provides an appropriate and effective locus for this important responsibility, and facilitates the consideration of oceanographic programs at the highest level of the executive branch. This top level support was made clearly evident in the President's letter of March 29,1961, to the presiding officers of the Senate and House, in which he recommended a $\$ 97$ million national oceanographic program for fiscal year 1962 .

4. The establishment of a division of marine sciences and an interagency committee in the National Science Foundation are also considered undesirable as a pattern of organization. Since various agency programs are necessarily related to this specialized mission and operational requirements, it seems to us inappropriate to place 
the coordinating mechanism in any single agency with responsibility for only a minor portion of the program. Also, the establishment of such a division of marine sciences would set a precedent pointing to the future creation of special units for various fields of science. 'This splintering of the organization of the Foundation would militate against the effective exercise of the Foundation's responsibility to support basic scientific research on the broad basis necessary to the overall strength of American science. Furthermore, while nonGovernment scientists render excellent service as advisers, it is inappropriate to vest them with operational responsibilities, which would be the case if the proposal to make non-Government scientists members of the interagency committee were adopted. Moreover, the advice of non-Government scientists is being solicited by the ICO in planning the program, and is also sought by the Specil Assistant. for Science and 'Technology in the review of the ICO recommended actions.

In view of the above-mentioned considerations and the vigorous national program which is not being undertaken, the Bureau of the Budget does not favor the enactment of S. 901.

Sincerely yours,

Phillip S. Hughes, Assistant Director for Legislative Reference.

'The General Counsel of the Treasury, II ashington, August 17, 1961.

Hon. Herbert C. Bonner,

Chairman, Committee on Merchant Marine and Fisheries, House of Representatives, Washington, D.C.

Dear Mr. Chairman: Reference is made to your request for the views of this Department on S. 901, to establish a program of oceanographic research.

The Coast Guard presently has limited authority in the field of oceanography, such as providing meteorological services from floating ocean stations and studying ice and current conditions in the North Atlantic Ocem (14 U.S.C.90; 46 U.S.C. 73Sa(a)). Ender its limited authority, the Coast Guard has been conducting oceanographic work on its eustern seaboard lightships and has been tal ing soundings and bathythermograph readings.

The President in his letter to the President of the Senate dated March 29, 1961, relating to a national oceanographic program, recommended that statutory limitations restricting participation by the Coast Guard in oceanographic research be removed. The Coast. Guard, with its fleet of vessels and other units, is particularly well adapted to assist in this scientific endeavor. General statutory sanction to conduct and engage in oceanographic prograns would nuke possible a greater contribution by the Coast Guard in that activity.

Your committee has favorably reported and the House of Representatives has passed H.R. 6845 , which is designed to give the Coast Guard such general authority to conduct oceanographic research. H.R. 6845 is presently in conference. Completion of congressional consideration of that proposal would provide the Coast Guard adequate authority in the oceanographic field and the enactment of $\mathrm{S}$. 901 is considered unnecessary. 
The Department has been advised by the Bureau of the Budget that there is no objection from the standpoint of the administration's program to the submission of this report to your committee.

Sincerely yours,

ROBERT H. KNIGHT,

General Counsel.

The Secretary of Commerce, Washington, D.C., August 22, 1961.

Hon. Herbert C. Bonner,

Chairman, Committee on Merchant Marine and Fisheries, House of Representatives, Washington, D.C.

Dear Mr. Chairman: This is in response to your letter of August 4,1961 , requesting the views of this Department on S. 901, an act to advance the marine sciences, to establish a comprehensive 10-year program of oceanographic research and surveys, to promote commerce and navigation, to secure the national defense, to expand ocean, coastal, and Great Lakes resources, to authorize the construction of research and survey ships and laboratory facilities, to expedite oceanographic instrumentation, to assure systematic studies of effects of radioactive materials in marine environments, to enhance the public health and general welfare, and for other purposes.

As indicated in its title, the purpose of the act is to provide for a coordinated, long-range program of oceanographic research and marine surveys. The act appears designed to implement the report of the Committee on Oceanography of the National Academy of Sciences, entitled "Oceanography 1960 to $1970 . "$

In the 2 years that have elapsed since the release of that report in 1959 , the executive branch has substantially expanded its efforts in the field of oceanography in a variety of ways, many of which took into account the recommendations made in the Academy's report. These efforts would be further intensified under the coordinated national program for oceanography recommended by the President in his recent message to the Congress providing for a balanced and flexible use of overall resources available for oceanography.

This Department has accomplished much in the field of oceanography in recent years. Highlights of accomplishments in the Coast and Geodetic Survey since issuance of the Academy report on oceanography would include: a 3-month oceanographic expendition by the ship Explorer; assignment of the ship Pioneer to exclusive deep sea oceanographic investigations; expansion of oceanographic observations by other ships within the framework of their regular operations. Several ships have been outfitted with special oceanographic equipment.

The level of oceanographic operations in the Coast and Geodetic Survey has progressed from an expenditure of $\$ 6$ million in fiscal year 1960 to $\$ 11$ million in fiscal year 1961. Moreover, $\$ 14$ million was orignally proposed for fiscal year 1962, to which President Kennedy's program added $\$ 10$ million for a total of $\$ 24$ million. A considerable portion of these increases has been allocated to ship construction. The additional funds requested for fiscal year 1962 included $\$ 9$ million for construction of a 3,000 -ton ship designed specifically for oceanographic operations on the high seas. It will be the 
first ship of this size to be built by the United States for that specific purpose. Furthermore, under the 1962 budget as approved the Coast and Geodetic Survey, in addition to the large oceanographic ship, was authorized to replace one class II vessel. The Survey will also greatly expand its work in research and development of oceanographic research instrumentation. Funds are also included for additional oceanographers and for extending the working season of the four major ships in the Survey fleet. Extension of the season will be equivalent to the addition of nearly 1 ship-year of oceanographic work using existing vessels.

The Weather Bureau's major effort in oceanographic research during the past few vears has been directed to a better understanding and improved prediction of the coastal flooding produced by hurricanes and other severe storms over the oceans. Pilot studies needed for the sound development of several other air-sea interaction problems have been conducted. Under the President's program, the Weather Bureau would step up its oceanographic research studies on the interaction between the sea surface and atmosphere as it relates to the exchange of heat and momentum. This research would account for about 30 percent of funds allocated to the Bureau for research under the President's program. Additional studies planned to develop improved techniques for storm surge forecasting would account for some 30 percent of the increased funding under the President's program. Accelerated procurement of specialized instrumentation such as infrared radiation thermometers and automatic marine meteorological observing stations to support these studies would take another 30 percent of the increased funds of the Bureau.

This Department believes that it now has adequate statutory authority to support its present and proposed oceanographic activities. Furthermore, we believe that these activities are adequately coordinated with the oceanographic programs of other agencies by the Interagency Committee on Oceanography (ICO) under the Federal Council of Science and Technology.

For the foregoing reasons we believe that enactment of legislation in the nature of $\mathrm{S} .901$ is unnecessary at this time.

The Bureau of the Budget adrises there is no objection to the submission of this report from the standpoint of the administration's program.

Sincerely yours,

\section{Edward Gudeman, Tnder Secretary of Commerce.}

\section{Department of the Interior, Office of the Secretary, Washington, D.C., August 22, 1961.}

Hon. Herbert Bonver,

Chairman, Committee on Merchant Marine and Fisheries, House of Representatives, Washington, D.C.

Dear Mr. Bonner: We have received from Hon. George P. Miller, chairman of the Subcommittee on Oceanography, a copy of committee print on H.R. 4276, a bill to expand and develop the aquatic resources of the United States including the oceans, estuaries, and rivers, the 
Great Lakes, and other inland waters, to enhance the general welfare, and for other purposes.

We appreciate the opportunity to comment on the committee print. As stated in our report of June 8, 1961, to your committee on this bill, we have a vital interest in the field of oceanography and we are sympathetic to the objective of this proposal. We do not, however, recommend enactment of this bill for the reasons stated in our previous report.

Your committee has requested our views also on S. 901, a bill to advance the marine sciences, to establish a comprehensive 10-year program of oceanographic research and surveys, to promote commerce and navigation, to secure the national defense, to expand ocean, coastal, and Great Lakes resources, to authorize the construction of research and survey ships and laboratory facilities, to expedite oceanographic instrumentation, to assure systematic studies of effects of radioactive materials in marine environments, to enhance the public health and general welfare, and for other purposes. We submitted a report to the Committee on Interstate and Foreign Commerce, U.S. Senate, on April 24, 1961, on this bill. A copy of our report is enclosed. You will note that while we concurred in the general object of that bill we recommended that no action be taken on it for certain reasons, as set forth in the report.

We find no reason to alter our recommendation on this measure. In the event that your committee considers the measure favorably, however, we would wish to propose a number of amendments relating to the oceanographic activities of this Department.

The Bureau of the Budget has advised that there is no objection to the presentation of this report from the standpoint of the administration's program.

Sincerely yours,

Frank P. Briggs, Assistant Secretary of the Interior.

Department of the Interior, Office of the Secretary, Washington, D.C., April 24, 1961.

Hon. Warren G. Magnuson, Chairman, Committee on Interstate and Foreign Commerce, U.S. Senate, Washington, D.C.

Dear Senator Magnuson: Your committee has requested a report on S. 901, a bill to advance the marine sciences, to establish a comprehensive 10-year program of oceanographic research and surveys, to promote commerce and navigation, to secure the national defense, to expand ocean coastal, and Great Lakes resources, to authorize the construction of research and survey ships and laboratory facilities, to expedite oceanographic instrumentation, to assure systematic studies of effects of radioactive materials in marine environments, to enhance the public health and general welfare, and for other purposes.

We concur in the general object on this bill; however, notwithstanding our considerable interest in oceanographic research, we recommend that no action be taken on this bill for two principal reasons hereafter stated. 
First, as stated in our report of May 16, 1960, to your committee, concerning S. 2692 of the 86th Congress, this Department is already engaged in carrying out certain types of oceanographic research. Our report stated also that while this Department concurred in the objectives of such proposal, we have authority to carry out such research and did not believe enactment of the proposed legislation was necessary. We believe the enactment of S. 901 is umnecessary also for the same reasons and might inhibit the flexibility of oceanographic research programs.

Secondly, a coordinated and intensified national program for oceanography has been recommended by the President in his recent messages to the Senate and House. We believe that, if adopted, this program would provide a balanced and effective use of overall resources available for oceanography.

For the foregoing reasons, we believe that action on S. 901 would be unnecessary at present. We wish to emphasize, however, our great interest in the subject of oceanography and our desire that this form of research proceed efficiently and advantageously in the national interest. Four bureaus of this Department, our Bureau of Commercial Fisheries, our Bureau of Sport Fisheries and Wildlife, our Bureau of Mines, and the Geological Survey are directly concerned with the field of oceanography. We are prepared to contribute our share, to the extent that funds may be appropriated, toward accomplishment of the general objective of oceanographic research.

The Bureau of the Budget has advised that there is no objection to the presentation of this report from the standpoint of the administration's program.

Sincerely yours,

\author{
JoHN M. KeLLY, \\ Assistant Secretary of the Interior.
}

Nitional Science Foundation,

OfFice of The Director, Washington, D.C., January 23, 1962.

Hon. Herbert C. Bonner,

Chairman, Committee on Merchant Marine and Fisheries, House of Representatives, Washington, D.C.

Mr Dear Mr. Bonner: This is in further reply to your request for the views of the National Science Foundation on S. 901, the Mariae Sciences and Research Act of 1961.

We are in complete accord with the objectives of S. 901, which is aimed at assuring that the United States has a strong national oceanographic program. In this connection, it is estimated that the Federal effort in oceanography for fiscal year 1962 will amount to approximately $\$ 98.8$ million. Of this amount approximately $\$ 17$ million is available tor the oceanographic activities of the National Science Foundation. We feel that these amounts will enable the Federal Government to continue to strengthen its oceanographic research program in a sound manner.

With respect to the National Science Foundation, in addition to authorization of appropriations, S. 901 would direct the establishment of a Division of Marine Sciences in the Foundation, with a divisional committee consisting of representatives of various of the Federal 
agencies engaged in oceanographic research activities, together with six non-Federal scientists designated by the National Academy of Sciences-National Research Council. When the National Science Foundation was established, the Congress wisely provided for divisions concerned with general branches of science as, for example, the mathematical, physical, and engineering sciences, and the biological and medical sciences. After careful consideration of the matter, we have concluded that establishment of divisions on the basis suggested in the bill would not be as sound an arrangement and could lead to distortion and overlap in administration. Then, too, there would seem to be equally appropriate reasons for establishing other divisions in the Foundation for particular scientific disciplines which could lead to further organizational difficulties. At present, the Foundation is supporting oceanographic research activities through its existing divisions among which there is extremely close cooperation and coordination. To aid in carrying out these responsibilities, the Foundation has three full-time persons on its staff primarily concerned with oceanographic research matters, two in the Division of Mathematical, Physical, and Engineering Sciences and one in the Division of Biological and Medical Sciences. Our organizational arrangements for handling cross-disciplinary fields such as oceanography is a matter to which we are paying close attention, however, and we will not hesitate to change them as circumstances warrant.

One of the primary objectives of S. 901 is to assure that there is a continuing national policy and program for carrying out the Nation's oceanographic effort. Coordination of the activities of the Federal agencies in this area is presently the responsibility of the Federal Council for Science and Technology, whose Chairman is the Special Assistant to the President for Science and Technology, and which has established the Interagency Committee on Oceanography with representation from various Federal agencies including the Foundation. It is, of course, important, in the carrying out of the national program, that full information be available with respect to the status of the national effort, both public and private, and the needs in particular areas of this endeavor. The National Science Foundation, in carrying on its support of basic research in oceanography and related fields, keeps in close touch with oceanographic research activities throughout the world. In this connection we are planning to issue, at appropriate intervals, reports on the status of oceanographic research together with assessments, as appropriate, of national needs in this area.

We are deeply mindful of the importance of oceanographic research to the national welfare and are prepared to cooperate in any way possible to assure that the oceanographic effort of the United States is second to none.

The Bureau of the Budget has advised us it has no objection to the submission of this report from the standpoint of the adninistration's program.

Sincerely yours,

Alan T. Waterman, Director.

There are no changes in existing law. 

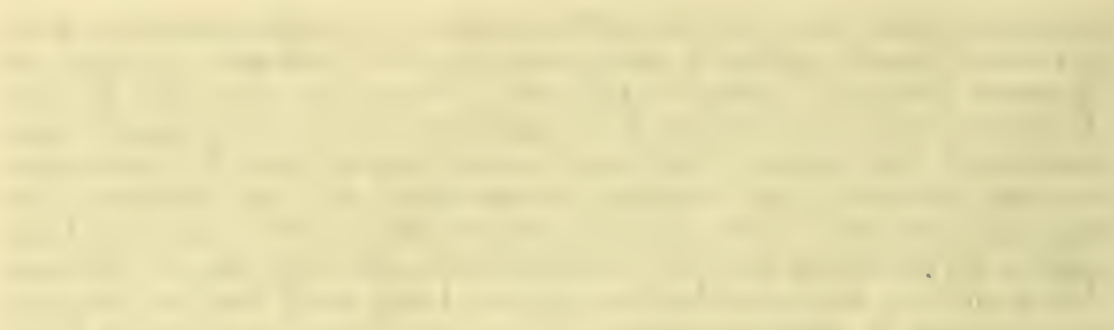